\title{
Heidegger och nazismen
}

\section{Av Roddy Nilsson, fil.dr i historia}

\author{
Länk till presentation av Roddy Nilsson
}

Få personer i förra århundradets intellektuella liv har i samma utsträckning varit föremål för skiftande omdömen som den tyske filosofen Martin Heidegger (1889-1976). Var han århundradets störste filosof, en obegriplig mystiker eller farlig charlatan? Frågan har naturligtvis djupt kommit att färgas av Heideggers anslutning till nazismen under 1930talet. Det är idag knappast möjligt att läsa eller diskutera Heidegger utan att också denna fråga kommer upp. Kring detta har en särskild genre av heideggeriana vuxit fram under de senaste femton åren. Debatten startade på allvar med Victor Farías bok Heidegger et le nazisme som först utgavs i Frankrike 1987.[1] Därefter har en strid ström av böcker och artiklar producerats som ur olika synvinklar diskuterat vad som kommit att kallas "fallet Heidegger."[2] Det stora intresse som detta rönt kan inte enbart förklaras med att det handlar om en berömd filosof. I vidare mening handlar det också om frågor kring den intellektuelles politiska och moraliska ansvar.

Det var länge en utbredd uppfattning att Heideggers engagemang för nazismen var en kortvarig affär som utspelades vid mitten av 1930-talet, ett beklagansvärt men tillfälligt avsteg som hade mycket litet att göra med den verklige filosofen Heidegger. Under det senaste decenniet och har dock nya fakta och pusselbitar kommit i dagen, som sammantaget visar att Heideggers engagemang för nazismen var mycket djupare och långvarigare än vad man tidigare trott. Trots att Heidegger själv hävdat att han tog avstånd från nazismen redan vid mitten av 30-talet skrev han 1942 om den "historiska singulariteten i nationalsocialismen". Ännu 1943 talade han om tyskarna som västerlandets "räddande kraft."[3]

Även om man bortser från problematiken kring Heideggers anslutning till nazismen har hans filosofi alltid varit omstridd. Hans filosofiska huvudverk Sein und Zeit (Varat och Tiden) utkom redan 1927.[4] Samma år blev han professor i Freiburg. Verket kan sägas vara ett storstilat försök att tänka om hela den västerländska filosofin och har som sådant fått mycket stort inflytande. Heideggers tidiga filosofi beskrivs ofta som ett försök att bygga upp en fundamentalontologi, ett sätt att tänka där tillvarons mening framträder som olika existensformer eller vad Heidegger kallade existentialer.

Heideggers filosofi liknar ingen annans och framstår vid en ytlig betraktelse som raka motsatsen till den analytiska filosofins strävan efter klarhet och logik i språket. Själv menade han att det endast var genom att gräva sig ner till språkets rötter som man kunde närma sig frågorna om varats väsen, vilket resulterade i ett skrivsätt fyllt av etymologiska härledningar och neologismer. För många har Heidegger framstått som sinnebilden för en obegriplig filosof. Heidegger talar om strävandet efter en "varaförståelse av varandets vara" och att vi befinner oss i något han kallar "i-världen-varo". Vi är "kastade" ut i världen. Följaktligen karaktäriseras vår tillvaro av vad han kallar "kastadhet". Ett par skor besitter vad han kallar "skohet" etc. Till och med "intet" får en substantivform hos Heidegger och blir till "intighet". Ibland närmar sig Heideggers språk dock närmast poesins som när han talar om att vi ska "lyssna till varats röst" eller att "språket är varats hus". Inom den anglosaxiska filosofin med dess betoning på olika former av analytisk tänkande och empirism har man tagit tydligt avstånd från Heideggers tyska tänkande, vad man med en dubbeltydig term kallat "Black Forest Philosophy". Symptomatiskt är att Heidegger inte ens nämns i Bertrand Russells stora verk om västerlandets filosofi. Heideggers filosofi har heller aldrig fått något större inflytande i vårt land. Också här har den analytiska filosofen 
varit stark. Gunnar Fredriksson har beskrivit Heideggers språkanvändning som en strid ström med ständigt nya termer, som ofta lämnas helt odefinierade eller som definieras med andra, nya termer som är ännu dunklare.[5]

Som lärare och föreläsare gjorde sig Heidegger tidigt ett namn. Flera av 1900-talets ledande intellektuella gestalter studerade under mellankrigstiden för Heidegger: 60talsvänsterns ikon Herbert Marcuse, Karl Löwith, Hannah Arendt - med vilken han också hade en omtalad kärleksaffär[6] - och Hans-Georg Gadamer är några av de mest kända. Hans filosofi kom sedan också på ett djupgående sätt att påverka den moderna franska exitentialismen hos Sartre och Camus.

Strax efter det nazistiska maktövertagandet 1933 valdes Heidegger till rektor vid universitetet i Freiburg. Under sin kortvariga rektorstid engagerade sig Heidegger starkt för den nazistiska nyordningen både inom och utom universitetet och hans installationsföreläsning formades till en appell för universitetets uppslutning bakom regimen.[7] Ännu tydligare framgår Heideggers engagemang i de tal och appeller som tillkom i samband med den av nazisterna anordnade folkomröstningen om att utträda ur Nationernas Förbund 1933 där han uppmanade universitetets studenter och lärare att ge sitt förbehållslösa stöd åt denna politik.[8] Språkbruket i uttalandena från denna tid är en blandning av filosofiskt språkbruk och nazistisk kampretorik där nationens öde länkas till den store ledaren Adolf Hitler. Framtiden var oupplösligt förbunden med Hitler, menade Heidegger. Führern ensam var den tyska realiteten och dess lag, och det tyska folket måste frivilligt underkasta sig hans vilja. Endast genom att följa Hitler och nazisterna kunde den tyska nationen vinna tillbaka sanningen i sin existens.[9]

Det råder ingen tvekan om att Heidegger under 1930-talet såg nazismen som den kraft som skulle rädda Tyskland. För Heidegger var nazismen mycket mera än en politisk rörelse. Den hade en "inre sanning och storhet"[10] som låg djupare än andra ideologier. Det är tydligt att han liksom många andra inom den konservativt inriktade intelligentian i

Tyskland drogs med av den våldsamma kraften i den nazistiska rörelsen. I det konglomerat av disparata idéer som utgjorde nazismens program fanns flera inslag som kunde appellera till den bild av kris och förfall som dominerade dessa kretsar. I framhållandet av nationen das Volk - , antimodernismen och elitismen och i motståndet mot kommunismen, liberalismen och demokratin formades en för den tyska högern gemensam världsbild.[11]

Nationalsocialismen skulle, menade Heidegger, leda till en andlig pånyttfödelse för det tyska folket. Tyskland befann sig i en djup kris som endast nationalsocialismen kunde rädda landet ifrån. Krisen var inte bara politisk utan även något som rörde den tyska anden i djupet. I detta ögonblick var det filosofernas och övriga lärdas plikt att följa Führern. Under tiden som rektor stödde Heidegger också aktivt den politik som gick ut på att avlägsna judar och andra för regimen misshagliga element från poster vid universiteten. Heidegger ville dock gå längre än så. I varje fall under en kort tid såg han sig som den som skulle bidra till att den nationalsocialistiska revolutionen fick en andlig dimension.

Den nazistiska regimen var emellertid inte särskilt intresserad av att låta sig ledas i mera andlig - geistlich - riktning och Heidegger avgick från posten som rektor redan efter tio månader. Därefter avlägsnade han sig från politiken och under den återstående tiden av den nazistiska eran var han enbart verksam som lärare. Hans filosofiska arbete vändes allt mera mot estetiken, bort från den omedelbara varaproblematik som tidigare stått i centrum. Han kvarstod dock som medlem i nazistpartiet fram till 1945. Hans samröre med nazisterna ledde till att han efter kriget fråntogs rätten att undervisa fram till 1951. Tiden efter avstängningen och fram till pensioneringen 1959 var en mycket produktiv period i Heideggers liv. Under de sista åren av sitt akademiska liv tillbringade han mer och mer tid i Todtnauberg, en plats i Schwarzwald, vars stämningsmättade namn för många blivit synonymt med hans dunkla filosofi.

Frågan är då om det finns något samband mellan Heideggers filosofi och hans anslutning till nazismen. Finns det i Heideggers tänkande något som också kan förklara hans dragning 
till nazismen? Den verkligt stora gåtan är kanske inte varför Heidegger över huvud taget blev nazist under 1930-talet. Kanske inte heller om det finns en affinitet mellan hans filosofi och nazismen.

Den fråga som för många framstår som den svåraste att besvara och mest komprometterande för Heidegger och hans försvarare är den om hans agerande efter kriget. Heideggers svar till dem som efter kriget sattes att granska vad som skett under den nazistiska perioden innehåller en rad lögner, eller i varje fall kraftiga tillrättalägganden.[12] Faktum är att han aldrig offentligt tog avstånd ifrån nazismen. Inte en enda gång förmådde han sig till tala om Hitlers brottslighet, om Auschwitz, Förintelsen eller nazisternas andra övergrepp. Vid de få tillfällen han berörde dessa ämnen gjorde han det inom en filosofisk diskurs som föranlett en rad tolkningar.[13] Inte ens i den berömda intervjun med två journalister från Der Spiegel 1966, publicerad först efter Heideggers död tio år senare, finns några tydliga svar.[14]

Det är framför allt tre passager hos Heidegger som föranlett häftig kritik.[15] Den första återfinns i ett brev 1948 till hans före detta elev Herbert Marcuse vilken i ett tidigare brev uppmanat Heidegger att förklara sitt agerande under kriget. Efter att ha presenterat ett antal föga klargörande svar avslutar Heidegger sitt brev med att jämställa judarnas öden under den nazistiska regimen med fördrivandet av tyska befolkningsgrupper från östra Europa efter kriget.[16] Året därpå höll Heidegger ett antal föreläsningar där han vid två tillfällen indirekt berörde Förintelsen. I en utläggning om den moderna tekniken hävdade han att "jordbruket blivit en mekaniserad livsmedelsindustri, väsentligen samma sak som fabrikationen av lik i koncentrationslägrens gaskammare."[17] Orden uttrycker, som Daniel Birnbaum och Sven-Olov Wallenstein understryker i sin lilla läsvärda bok Heideggers väg, en djup okänslighet och en nära nog total avsaknad av skuldmedvetenhet. Förintelsen blir till en episod i varats historia, till något förknippat med den moderna teknikens väsen, och därmed i sista hand något som kan frita både honom själv och nazisterna från historiskt ansvar.[18] Samma dag som detta uttalande gjordes höll Heidegger ytterligare en föreläsning där han bland annat talade om dem som dött i koncentrationslägren. Han jämförde här de "hundratusentals" som dött under nazisttiden med de "miljoner" som nu påstods svälta ihjäl i Kina. Några rader längre ned finns en dunkel mening som talar om innebörden av att dö en autentisk död, vilken kan tolkas som att Heidegger menar att offren för den nazistiska utrotningspolitiken inte dog en "riktig" död. För att dö en autentisk död måste man vara en del i en historisk gemenskap som binds samman av något i djupare mening ödesbestämt.[19]

Hur ska då Heideggers förhållande till nazismen och dess brott tolkas? Kan det vara så att nazisttiden och Förintelsen för Heidegger på något märkligt sätt framstod som en alltför trivial händelse i den stora varahistorien för att vara värd att nämna? Vad kunde Heidegger ha sagt annat än opportunistiska plattityder? Om människan saknar ord för att beskriva det oerhörda som hände under nazisttiden kanske tystnaden är den enda möjliga hållningen. Måhända är svaret på frågan varför Heidegger aldrig offentligt tog avstånd från nazismen mera trivialt än vad många har velat erkänna. Det är möjligt att Heidegger varken för sig själv eller andra kunde erkänna sitt misstag när han lät sig svepas med i entusiasmen för nazismen. Kanske han kände en skam för att han i sin fåfänga och naivitet trodde att han skulle kunna påverka den nazistiska ideologin i mera andlig riktning. Hans ovilja att ta avstånd från nazismen skulle i så fall mycket mera ha att göra med oförmågan att erkänna sitt personliga misslyckade än kvardröjande sympatier för nazismen.

Farías menar att tystnaden och den undanglidande strategin hos Heidegger snarast är ett bevis för att han livet igenom hyste nazistiska sympatier. Detta menar de flesta andra bedömare är att gå för långt. Däremot har flera forskare pekat på hur både hans agerande under kriget och hans uttalanden efteråt bara kan förstås i ljuset av hans filosofiska tänkande. En rad forskare har framhållit hur centrala begrepp i Heideggers filosofi hade en motsvarighet i eller i varje fall är förenligt med drag i det nazistiska tänkandet.[20] Birnbaum och Wallenstein är inte lika kategoriska, men finner även de beröringspunkter.[21] Andra har förnekat att det finns samband mellan Heideggers filosofi 
och nazismen.[22]

Det finns dock ytterligare en dimension i sammanhanget som jag tror är viktig för att förstå Heideggers agerande. Den starka kritik som under de senaste åren riktats mot Heidegger för hans långa tystnad och förnekande har haft en märkligt ohistorisk slagsida. I själva verket var Heideggers strategi på många sätt symptomatisk för tillståndet i efterkrigstidens Västtyskland.[23] De otillräckliga förklaringarna, frånvaron av tydliga avståndstaganden och den allmänna tystnaden om vad som hänt under nazisttiden var i själva verket karaktäristiska för en stor del av den generation som Heidegger tillhörde. Även med detta i åtanke vilar skuldbördan hur som helst tungt på Heidegger, i synnerhet som en av hans egna grundtankar var att filosofin inte går att skilja från livet i övrigt.

\section{(C) $\underline{\text { Roddy Nilsson }}$}

[1] Victor Farías, Heidegger et le Nazisme, Lagrasse: Verdier 1987. Engelsk översättning Heidegger and Nazism, Philadelphia 1989.

[2] Otto Pöggeler, Martin Heidegger's Path of Thinking, Atlantic Highlands 1987; Jaques Derrida, Of Spirit: Heidegger and the Question, Chicago 1990; Luc Ferry and Alan Renault, Heidegger and Modernity, Chicago 1990; Philippe Lacoue-Labarthe, Heidegger, Art, and Politics, Oxford 1990; Jean-Francois Lyotard, Heidegger and the Jews, Minneapolis 1990; Günter Neske and Emil Kettering (eds), Martin Heidegger and National Socialism: Questions and Answers, New York 1990; Richard Wolin, The Politics of Being: The Political Thought of Martin Heidegger, New York 1990; Richard Wolin (ed), The Heidegger Controversy. A Critical Reader, Cambridge, Mass och London 1991; Pierre Bourdieu, The Political Ontology of Martin Heidegger, Cambridge 1991; Tom Rockmore, On Heidegger's Nazism and Philosophy, Berkeley och Los Angeles 1992; Tom Rockmore and Joseph Margolis (eds), The Heidegger Case: On Philosophy and Politics, Philadelphia 1992; John D Caputo, Demythologizing Heidegger, Bloomington 1993; Hans Sluga, Heidegger's Crisis: Philosophy and Politics in Nazi Germany, Cambridge, Mass och London 1995; Alan Milchman and Alan Rosenberg (eds), Martin Heidegger and the Holocaust, Atlantic Highlands 1996; Berel Lang, Heidegger's Silence, Cornell 1996; Julian Young, Heidegger, Philosophy, Nazism, Cambridge 1997. På svenska finns Hugo Ott, Fallet Heidegger, Göteborg 1991. Till en del tangeras problematiken också i George Steiner, Martin Heidegger - en introduktion, Göteborg 1997, Elzbieta Ettinger, Hannah Arendt, Martin Heidegger, Stockholm 1997 och Daniel Birnbaum och Sven-Olov Wallenstein, Heideggers väg, Stockholm 1999.

[3] Richard Wolin, "Introduction, 'Over the Line', Reflections on Heidegger and National Socialism", i Wolin (ed), s 14.

[4] Svensk översättning Varat och tiden, del 1 och 2, Lund 1981.

[5] Gunnar Fredriksson, 20 Filosofer, Stockholm 1994, s $239 \mathrm{ff}$.

[6] Se Ettinger.

[7] Heideggers installationstal finns i svensk översättning med titeln "Det tyska universitetets självhävdande", i Birnbaum och Wallenstein, s 77-87.

[8] Dessa återges i engelsk översättning i Wolin (ed), s 46-52.

[9] Wolin (ed), s 47.

[10] Wolin, "Introduction...", i Wolin (ed), s 2.

[11] För en diskussion kring denna problematik se t ex Sluga.

[12] Se Ott, s 253ff.

[13] Se Milchman och Rosenberg (eds).

[14] Intervjun finns i engelsk översättning under titeln "Only a God can save us" i Wolin (ed), s 91-116.

[15] Heideggers arkiv i Marburg är inte tillgängligt för forskningen varför många frågor kring honom ännu är obesvarade.

[16] Marcuses och Heidegger brev återfinns i engelsk översättning i Wolin (ed), s 160-164.

[17] Birnbaum och Wallenstein, s 76.

[18] Birnbaum och Wallenstein, s 76.

[19] George Leaman, "Strategies of Deception", i Milchman och Rosenberg (eds), s 61f. 
[20] Se t ex Wolin, Rockmore, Lang samt Leaman, "Strategies..."; Wilhelm S Wurtzer, "Heidegger's Silent Inhumanity: 'To think the Nobility of Being..."'; Tom Rockmore, "Heidegger and Holocaust Revisionism", i Milchman och Rosenberg (eds).

[21] Birnbaum och Wallenstein, s 64ff.

[22] Se t ex Derrida, Lacoue-Labarthe samt Young.

[23] Se t ex Leaman, "Strategies..."; Rainer Alisch, "Heidegger's 'Silence' about the

Holocaust: An Attempt at a Reconstruction", i Milchman och Rosenberg (eds) samt Sluga. 